\title{
Disruption in Economics Learning through WhatsApp Group during Covid-19 Pandemic
}

\author{
Raden Roro Suci Nurdianti ${ }^{1 *}$ \\ ${ }^{1}$ Department of Economics Education, Universitas Siliwangi, Indonesia \\ "Corresponding author. E-mail : radenrorosucinurdianti@unsil.ac.id
}

\begin{abstract}
The word 'Disruption' becomes more popular along with Industrial Revolution 4.0. This word appears in various aspects of life: socioeconomic, financial, transportation, and even educational aspects. This change called Disruption is challenging to some countries. But for some others, it can also help facilitate the society in facing various phenomena, for example, the current issues covid-19 pandemic that happens all over the world. The aim of this study is to describe how economics learning can be done at a distance during the pandemic, using WhatsApp Group media, especially in Indonesia. Many teachers, students, lecturers, and college students use this media to keep the learning going during home-learning phenomenon during this pandemic time. The methods used in this study is literature review, by collecting various theory, books, journals and data related to the use of WhatsApp in teaching and learning. The results show that, WhatsApp Group helps the communication between students and teachers, especially when learning takes place from different location, but it still has a lot of weakness and cannot be used in long term. Learning in class still becomes the first choice in Indonesia even though the education systems start to disrupt digitally, departing from this home-learning phenomenon.
\end{abstract}

Keywords : Disruption, Economics Learning, WhatsApp Group

\section{INTRODUCTION}

The spread of COVID 19 makes people change their routine to minimize the impact of the viruses itself. So, many of peoples activities are done at home, including school activities. This pandemic makes classroom move from school to home. As said in the Jakarta Post's article on June 2020, The Education and Culture Ministry has confirmed that, as of March 16, 67 Indonesian universities had used virtual learning methods. A lot of universities use newest Learning Management Systems (LMS) that can help both teacher and students learn effectively at home. But, because not all of these people can easily use the systems, some of them are trapped into situation that has to be done as soon as possible during the home learning. Then using WhatsApp is the fastest answer.

Taking from the description at WhatsApp application, WhatsApp Messenger is a FREE messaging app available for iPhone and other smartphones. WhatsApp uses your phone's Internet connection $(4 \mathrm{G} / 3 \mathrm{G} / 2 \mathrm{G} / \mathrm{EDGE}$ or $\mathrm{Wi}$ -
$\mathrm{Fi}$, as available) to let you message and call friends and family. Switch from SMS to WhatsApp to send and receive messages, calls, photos, videos, documents, and Voice Messages, so, WhatsApp Messenger can help us connect each other by sending messages, documents, videos, etc. Not only used in communicate between people in real life, this apps also used in learning and teaching.

Teachers have to start to use the new technologies and explore their effects on student performance. This technology makes a lot of influence on the teaching methods and models, especially in classes full of young students.

In economics learning in traditional class, teacher and students usually take various models of learning to improve the teaching materials inside the subject. In economics learning, usually we need a lot of pictures, mathematical functions, and data literacy to complete the subject itself. During the COVID 19 pandemic, this traditional classroom cannot be organized as usual. So, the classes turned into virtual classes by which teacher and students connect to ech other from afar. Most of the economics teachers and lecturers in Indonesia use WhatsApp group to keep the classes going during the pandemic. So, this paper will 
describe about the disruption in economics learning using WhatsApp Group during COVID 19 pandemic, especially in Indonesia.

\section{LITERATURE REVIEW}

\section{a. Disruption in Teaching and Learning}

The development of knowledge is getting faster as the world keeps moving forward. Digitalization starts to get into the society, so people need to fit with the new era. The world now is entering into the great Shocks as Fukuyama's writing, "The Great Disruption". So, what is Disruption?

As Fukuyama said, Disruption means disturbance or chaos. He thinks that people controlled with power of information respect more the value of freedom and equality. The freedom to choose showed up as the right of every human. Fukuyama said there is an advantage of the innovation, so the society changes into the "information society".

Disruption is an innovation. This innovation will change the old systems with newest ways. Disruption potentially changes the old player with the new one. Disruption changes the old technology with digital technology that makes something new, efficient, and useful[5]. Something new in this era has started since people use the internet and smartphones. The Internet of Things (IoT) reaches almost all of important subjects in life: Health, Education, Economy, Transportation, Trade, etc.

In education, the disruption happens both in the systems and the learning processes itself. Disruption in education systems can be seen from online school registration, recruitments, meetings, and many more. On the other hands, disruption in teaching and learning can be seen from the use of virtual classes, online learning media, learning videos, game based virtual learning, and online assessment.

According to Ajar Kochar, et al [2] , "Social media outlets, such as Twitter, have become popular in academic circles by exposing trainees and faculty alike to a far broader audience, allowing direct discussion with content experts, democratizing voices, and delivering high-yield teaching points in short and consistent units. Social media also amplifies the reach of medical conferences and enhances the dissemination, academic discussion, and peer review of novel trials and research endeavors".

\section{b. Teaching and Learning Through WhatsApp Group}

According to Ajar Kochar, MD, MHS, Jennifer Rymer, MD, MBA, Zainab Samad, MBBS, MHS [2]:

WhatsApp allows us to rapidly share and to discuss educational material through a group text, case-based format. Participants post interesting cases, often with images (electrocardiograms, echocardiograms, cardiac catheterizations, hemodynamic tracings, computed tomography images, and magnetic resonance images), and the group engages in discussions regarding diagnosis and management plans. All participants are required to remove protected health information before posting cases. The goal of the group text is to share individual case based teachable moments to the entire fellowship program and stimulate interesting discussions. We chose WhatsApp as the interactive platform, because it allowed instantaneous messaging, unlimited number of participants, end-to-end encryption of texts, and the ability to evaluate participation and engagement with cases. The group text allows for administrative rights, so that faculty/fellow leads can ensure protected health information exclusion and keep discussions focused on education.

Plana et al.[4] write paper about the use of WhatsApp in English subject between students in Spain. The result showed the rise in motivation and a bigger enthusiasm for reading in foreign language. Concerning the use of the instant messaging system, to avoid creating a WhatsApp group with all the subjects, encouraging learners to divert from the focus of the method and interact amongst themselves regardless of the experiment, the learners were distributed into groups of 10 and the messages sent in sequenced bulks. To conclude, despite the various limitations, a vast majority of the students reported a high level of satisfaction and agreed that not only had their willingness to read in English increased, but the experience had also had a positive impact on their reading habits, and had resulted in more regularity and confidence.

Meanwhile, Gina Lundberg, MD [3] said that, WhatsApp is cheap, easy, accessible, and a rather simple educational model. It is a flexible platform and can be brief or extended depending on the level of engagement. The cons are that few faculties are embracing the benefits and importance of social media and mobile phone apps for medical education. If faculty do not value these novel modalities, they are less likely to be engaged. The authors have acknowledged that being on your mobile phone can appear disruptive and rude in a clinical setting. The authors showed sensitivity and responsibility through the development of a code of conduct for their mobile app-based education tool. Thus, these issues have been adequately addressed.

Amry [1] said that mobile learning based WhatsApp social networking has a high positive impact on the achievement test of students. Students prefer this innovative educational technology based mobile learning. The results of the achievement test, which were realized after the end of the experimental period, show that arithmetic. 


\section{RESULT AND DISCUSSION}

Economics subject basically needs a lot of description, mathematical functions, diagrams, and picture as the theory visualization. Sometimes discussion methods can be done when the learning models are based on real situation. So, various models and methods of teaching really are needed for economics subject.

When COVID19 pandemic happens and both teacher and students have to learn at home, the class hard to change into virtual classroom because some of the student they don't have the facilities to the internet, just like mobile phone and internet. Meanwhile, the network is not really good for some places around West Java, Indonesia. So, they do not have a lot of choice to use platforms to learn. The easiest way can be done is using WhatsApp as learning media during the home-learning activity.

WhatsApp becomes the easiest way to keep the learning going even the students and teacher at different places. The teacher still can present in class, using "group" facilities. They can create the group and also named it based on real class at school. For example, class A, class B, etc. At picture 1, we can see the examples for groups in Industrial Economics classes divide in A, B, C classes.

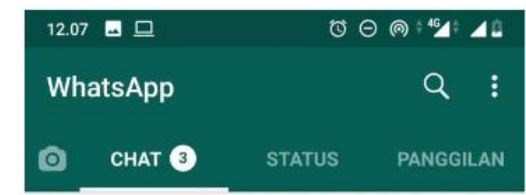

KELAS A EKONOMI INDU

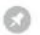

KELAS B EKONOMI INDU... 29/08/20

KELAS C EKONOMI INDU... 10/08/20

Picture 1. Group Class Industrial Economics Subject

Inside the group, teacher can begin the class with text explanation, voice note, or video. Teacher can also check the student presence with real-time presence or using another application and send the link so the student can fill the presence list for the day learning activities. In this sample, can be seen that teacher using google forms to check student's presence on class.

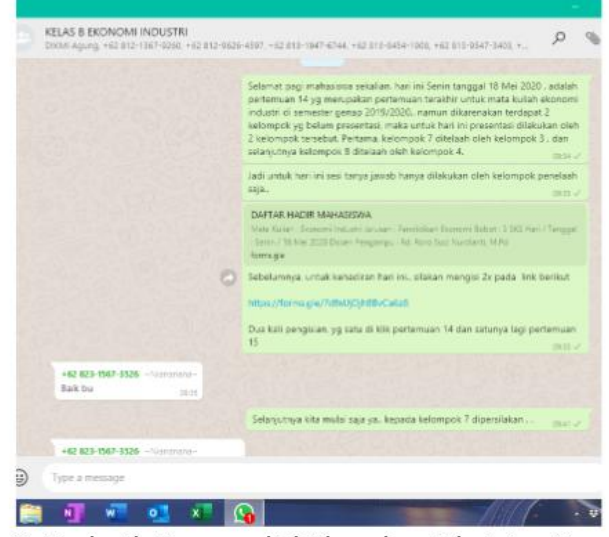

Picture 2. Student's Presence link Shared on WhatsApp Group Class

Then, if the class needs a lot of active discussion within students or teacher, this can be done with text message or voice note. The discussion needs a facilitator or moderator so it could be well-organized. From Picture 3, we can see some of the discussion happen on industrial economic classes, between students and teachers.

KELAS B EKONOMI IND...
+62 812-1367-9260, +62 813-954..
3. Bayu tri pamungkas 182165049
Apa faktor yg menjadikan perusahaan
mie indomie menjadi pasar no $1 \mathrm{di}$
antara yg lainnya dan selama kurun
waktu enam tahun terus menduduki
pasar, dari faktor apakah?
$\begin{aligned} & \text { Mungkin itu pertanyaan dari } \\ & \text { kelompok 4 }\end{aligned}$
+62 821-1897-1152
Untuk pertanyaan dari @Gina
zakiyyah akan dijawab oleh Shelvina
+62 896-9254-0121
Saya Shelvina Erma F 182165105
izin menjawab pertanyaan dari gina
mengenai dampak dari covid-19
terhadap industri manufaktur mie
instant, di Indonesia sendiri dengan
adanya wabah ini justru membuat

Picture 3. Discussion Inside the Group Class

When using WhatsApp for learning, we can keep the class going even when the people are in different time and place. The group can be used to give any information about the exercise, assignment, or else related to the subject. This makes the information spread really fast between students.

Is there any weakness of using WhatsApp for Economics Learning? Yes, of course, there is. First, when the students or teacher being in the area that have bad internet network, they cannot join the class properly. Second, using WhatsApp make students find difficulty in 
communicating in real-time with direct talk. The video call featured only limited to 8 person, meanwhile the students almost 30 person in each groups. Third, teachers find difficulty to watch students attention because they cannot see directly whether the students always on line from the smartphone, or just fill in the presence link and their leave their mobile phone. Direct Learning in real class still becomes the first choice of economics learning, as it is better than virtual class.

\section{CONCLUSION}

In emergency situation like this COVID 19 Pandemic, the disruption helps almost every activity keep going even in different places, including school. Online learning is the only choice when school is still closed, and both teacher and students have to do 'Home Learning' until next year. Using of WhatsApp Group for teaching and learning is the best answer to keep the learning going. In economics learning, using WhatsApp is really effective to share the learning materials, presentation, video or picture, and also link of student's presence in class. But the weakness is teacher lack of control, doesn't similar with direct learning in class which teacher can see students attention person by person. Direct learning in class is still being the first choice when the pandemic is ever and school open just like before pandemic.

\section{REFERENCES}

[1] Amry, A. B. (2014). The impact of whatsapp mobile social learning on the achievement and attitudes of female students compared with face to face learning in the classroom. European Scientific Journal, ESJ, 10(22). https://doi.org/10.19044/esj.2014.v10n22p\%p

[2] Ajar Kochar, MD, MHS\& Jennifer Rymer, MD, MBA,\&Zainab Samad, MBBS, MHS. (2017). Disrupting Fellow Education ThroughGroup Texting: WhatsApp in Fellow Education?Journal of the American College of Cardiology Vol 72 , n o. 2 5, 2018 8Published by Elsevier

[3] Gina Lundberg, MD. (2013). RESPONSE: What's App, Doc?. JACC VOL.72 , NO.25 , 2018Kocharet al.DECEMBER25, 2018 : 3366 -9

[4] Plana MGC, Escofet MIG, Figueras IT, Gimeno A, Appel C, Hopkins J.(2013).Improving learners' reading skills through instant short messages: A sample study using WhatsApp. 4th World-CALL Conference; Glasgow. 2013 Jul 10-13

[5] Rhenald Kasali. (2019) Disruption : Menghadapi Lawan-lawan tak Keihatan dalam Peradaban Uber. Jakarta : Kompas -Gramedia 